\title{
The State of Education in Malkangiri District of Odisha and Its Impact on the Human Capital Development
}

\author{
Subhra Parida
}

\begin{abstract}
Education is not the basis for civilization, it is civilization (Jay Newman, 1977) [1]. To be precise Civilization is the form of development of a community with the changing times evolving psychologically and intellectually at the same time. Education forms the basis on which the community evolves. There is no denying that education can elevate a person's standard of living which includes health, employment prospects, and income. While states like Kerala, Andhra Pradesh and Gujarat have definitely shown tremendous growth in literacy rate, States like Odisha and Bihar are still struggling to keep pace with them. Odisha has devised numerous programmes in order to fast-track the literacy rate. According to Census 2011 the literacy rate of Odisha rose to $72.9 \%$. Male and female literacy rates are $83.2 \%$ and $67.8 \%$ respectively. According to the Human Development Index (HDI) 2017 [2] India scored around 0.640 ranking $130^{\text {nd }}$ among 189 countries while Odisha scored 0.597 and ranked $32^{n d}$ out of the enlisted 36 States and Union Territories. Despite all the efforts the State was placed among the last 5 positions in the hierarchy. One of the reasons behind this disparity is because of the 8 most backward districts of the country constituting this state. Nuapada, Malkangiri, Nabarangpur, Boudh, Mayurbhanj, Gajapati, Kandhamal, Kalahandi are those 8 rundown districts which demand immediate attention. The HDI of these districts range between 0.12-0.15 making them least developed districts as far Human Capital is concerned. This paper will analyse the nuances of low education level in one of the most backward district of Odisha known as Malkangiri with that of the discrepancies faced by the residents and provide reasonable solution for it.
\end{abstract} living.

Keywords: Human capital, HDI, Literacy rate, Standard of

\section{INTRODUCTION}

Table 1.Millennium Development Goals for 2015:

\begin{tabular}{|c|c|}
\hline $\begin{array}{c}\text { Net enrolment ration in primary education } \\
\text { (both genders) }\end{array}$ & $88.08 \%$ \\
\hline $\begin{array}{c}\text { percentage of pupils starting Grade } \mathbf{1} \text { and } \\
\text { reach Grade } 5 \text { (both Genders) }\end{array}$ & $86.05 \%$ \\
\hline literacy rate of 15-24 year olds & $86.10 \%$ \\
\hline
\end{tabular}

Source: in.UNDP.org [3]

The World Bank Report states that the poor education level in India reflects in the low income level which adversely affects the standard of living of the earning member as well as his entire family. This disturbs the social, psychological and physical well-being of the person gradually.

Revised Manuscript Received on March 13, 2020.

* Correspondence Author

Ms. Subhra Parida*, Research Scholar, School of Humanities, Kalinga Institute of Industrial Technology, Bhubaneswar, Odisha.

(C) The Authors. Published by Blue Eyes Intelligence Engineering and Sciences Publication (BEIESP). This is an open access article under the CC BY-NC-ND license (http://creativecommons.org/licenses/by-nc-nd/4.0/)
According to the Millennium Development Goals (MDG) designed by the United Nations Development Programme for a holistic growth, India has shown considerable progress in providing universal education.

In 2015193 countries across the globe took another oath to eradicate poverty and other disparities which hinder the sustainable growth of a nation. This came to be known as the Sustainable Development Goals (SDG) [4]. As opposed to 8 goals of MDG, SDG enlisted 17 goals for the vision of a progressive, secure and healthy world by the year 2030. In order to fulfil the goals India has made significant contribution towards enabling development starting with provision of Universal education and reducing gender disparity evident in net enrolment of primary class students. According to the Indian Constitution Free and compulsory education for all students aged 6-14 has been chalked out under the Right of Children to Free and Compulsory Education Act 2009. With the objective to provide education to all irrespective of caste, creed, gender and class, the initiative looks promising to moderate the challenges of Universal Education. While the Central and State Government has put in a lot of effort in filling up the gaps, certain studies have put forward a different story altogether. According to Pratham's Annual Status of Education report [5] shows that $27 \%$ of Class VIII students in Government and private primary schools could not read a text from Class II books. Only $44 \%$ of students of Class V could read a text from Class II books. In order to get rid of poverty and backwardness, education has to be given more priority. In 2006 Confederation of Indian Industry (CII) launched 'India at 75 initiative'. It aimed to skill around 500 million people which is how the National Skill Development Council came into being. But as they say actions speak louder than words, so far only $5 \%$ of the workforce have been skilled as against $96 \%$ of skilled workforce in South Korea, $75 \%$ of skilled workforce in Germany and 52\% of skilled workforce in the United States of America. When we compare this statistics with other countries we get to know where we stand. This also one of the reasons behind the escalating unemployment rate in India. When the economy slows or suffers from recessionary forces, it is the uneducated and the unskilled who suffer. Skilling is not just about being skilled in technical aspects but also upgrading your knowledge of traditional craftsmanship so that the final product will get its worth and distress selling can be avoided. Adequate education also generates awareness. Awareness about physical, mental, social and psychological wellbeing is necessary to drive the young workforce of a country.

Published By:

Blue Eyes Intelligence Engineering \& Sciences Publication

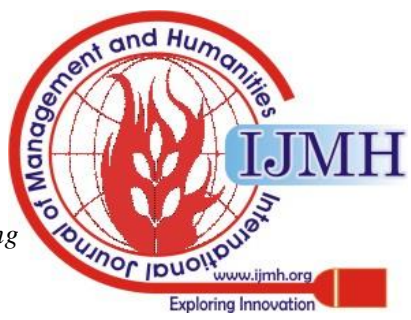


If a labourer is not aware about the healthcare facilities provided by the Government for his entire household or if a farmer is unknown to the insurance policies provided by the financial institutions for the security of his crops and income then the Government as well as the public both will be at a loss. He gets trapped in the vicious circle of poverty with an enormous amount of debt on his head. Very few states in India have introduced farm mechanisation. One of the reasons being lack of awareness. In the midst of all this chaos the most significant victims are the tribal people and absolute poor.

According to recent studies, Government expenditure on primary level education is low as compared to the higher and professional education. As remarked by the Nobel laureate Amartya Sen [6] the problem with Indian education is accessibility and affordability. Public expenditure should be diverted towards solving these problems primarily. Tribal communities do face a lot many difficulties in adapting the ideals of the modernistic society. Sujatha, K. (2002) [7] revealed that though education was not a critical demand among Scheduled Tribes, government policy focused on education as the main avenue by which to integrate them into mainstream society. But every new or modern initiative comes with its own baggage. The Pratichi Committee Report (2002) [8] identifies cost of schooling, lack of motivation of teachers, lack of inspection, and the increasing dependence on private tutoring to be the main hurdles in the path of education for tribal children. Even Scholars like Nirupam Bajpai, Ravindra Dholakia, Jeffrey D. Sachs [9] accept the fact that the complications in Indian education system lies in improving school infrastructure and functioning, curriculum and instructional resources, stricter control over teachers' training programme, and the quality and quantity of mid-day meals. Panchayati Raj Institutions (PRIs) have the ability to deliver the required efficacies and reduce the delivery gaps. Researchers even suggest the need for primary level teaching based on mother tongue for easier understanding and better grasp.

An economic model has been devised by Sylvia Kotásková, Petr Procházka and others [10] to analyse the impact of education on the economic growth of India. They used data from the World Development Indicators database (World Bank) to analyse the association between net enrolment ratios with that of the GDP product value at market prices. The equations which were extracted after Granger Causality and Stationarity Test are:

$$
\begin{aligned}
& \Delta y_{t}=\delta_{0}+\sum_{j=1}^{m 1} \delta_{1 j} \Delta y_{t-j}+\sum_{j=1}^{m 2} \delta_{2 j} \Delta z_{t-j}+\sum_{j=1}^{m 3} \delta_{3 j} \Delta x_{f t-j}+e_{1 t} \\
& \Delta y_{t}=\delta_{0}+\sum_{j=1}^{m 1} \delta_{1 j} \Delta y_{t-j}+\sum_{j=1}^{m 2} \delta_{2 j} \Delta z_{t-j}+\sum_{j=1}^{m 3} \delta_{3 j} \Delta x_{m t-j}+e_{1 t}
\end{aligned}
$$

The first equation signifies the impact of female education $\left(x_{f t}\right)$ on economic growth and the second equation signifies male education $\left(\mathrm{x}_{\mathrm{mt}}\right)$ on the economic growth of the nation. The paper concluded that both primary and senior levels of education are correlated with the economic growth of the nation and have a strong causal impact on the growth statistics. Not just that even tertiary education (graduation and above) do play an important role in influencing the growth and development of the nation but sadly this form of education is mostly dominated by males.

\section{RESEARCH GAP}

The previous research work has focused on how primary education level has improved in the country since independence and the way public expenditure has been allotted towards increasing attendance of male and female children who belong to the age group 5-10. In a nutshell most of the research work has focused on expanding the base of primary education level by improving budgetary allocation, providing quality education, reducing teacher absenteeism, promoting mid-day meals, building toilets for better health and hygiene. While all these aspects point out to the importance of asserting the requirement of education in a child's life. It will be important to study the impact of education level on the overall growth and wellbeing of person as well as family in a backward district such as that of Malkangiri.

\section{OBJECTIVE}

The paper will try to find out the discrepancies behind the low education level in Malkangiri and its impact on the HDI level. By just focusing on increasing schools and number of teachers, quality of education will be neglected which can dampen the objective of providing Universal education. So it is also important to discuss about providing quality education with increasing the net enrolment ratio. The following are the objectives:

- To analyse the primary level education in the district and state the fallacies involved.

- To study the impact of the low education level on the health and standard of living.

- To suggest ways and means to improve the situation in the district.

\section{METHODOLOGY}

In order to study the literacy rates and schooling effectiveness in the district it is first important to analyse the demography of the region and social indicators that highlight the standard of living of the people in the district. The paper will study the secondary data obtained from Prathams' Annual State of Education Report (Rural) 201819 and the district census handbook 2011- Malkangiri.

\section{DEMOGRAPHY OF MALKANGIRI DISTRICT}

Malkangiri is one the border districts of Odisha. It touches the border of Andhra Pradesh and Chhatisgarh. It is believed that the place derived its name from the word 'Malyaratnagiri' in Valmiki 'Ramayana'. It is here that Rishi Valmiki was enlightened with the view to script the epic "Ramayana". May it be the river 'Tamasa', the Shiva Linga or the Pandavas' sword being worshipped by the Koyas tribe, the district seems to be well connected to its roots. 
Besides the mythological significance the place holds, its rich flora and fauna, vivacious river system and mystical tribal history offers the district its identity.

Table 2.

\begin{tabular}{|c|c|}
\hline Population size & 612727 \\
\hline Tribal population & $77 \%$ \\
\hline No. of blocks & 7 \\
\hline Occupation & Agriculture (>90\%) \\
\hline Sex ratio & 1020 \\
\hline Child sex ratio & 992 \\
\hline Literacy rate & $48.54 \%$ \\
\hline Male literacy rate & $59.07 \%$ \\
\hline Female literacy rate & $38.28 \%$ \\
\hline
\end{tabular}

Source: District Census Handbook 2011 [11]

According to the Census 2011, tribal population comprises of about $77 \%$ of the total population of the district which are Bondas, Porajis, Didayis and Koyas. About $91 \%$ of the population depends on agriculture for their economy. While the sex ratio is better in comparison to the other districts. The literacy rate is way below State average (72.87\%) let alone National average.

Table 3.

\begin{tabular}{|c|c|c|}
\hline Literacy rate & & Percentage \\
\hline Scheduled tribes & total & 57.83 \\
\hline & males & 56.56 \\
\hline & females & 59.08 \\
\hline Scheduled castes & total & 22.55 \\
\hline & males & 23.07 \\
\hline & females & 22.04 \\
\hline
\end{tabular}

Source: District Census Handbook 2011

The above table states that the literacy rate of scheduled caste is way below that of the scheduled tribe in total. The worst affected are the scheduled caste females whose average literacy rate is only $22.04 \%$ which ascertains the fact that the scheduled caste require more attention as compared to the scheduled tribe community as far as education is concerned. One of the major reasons behind the lagging behind of SCs is the slow assimilation of this community into the mainstream because of the age old Varna system prevalent in the country. The other reasons behind this wide gap in literacy rate can be understood by delving into the standard of living of the population in this district.

The table below describes the condition of State in terms of enrolment of students and their level of knowledge from the class. The State has been divided into 3 regions Central, Northern and Southern. The Southern region is the area which comprises of all the backward districts including Malkangiri. While the Central region consists of the high literacy rate districts such as Khordha and Cuttack.
Table 4

\begin{tabular}{|c|c|c|c|c|}
\hline \multirow{4}{*}{ Region } & \multirow{4}{*}{\begin{tabular}{|c|} 
Not In School \\
\% of children \\
(age 6-14) not \\
enrolled in school
\end{tabular}} & \multirow{4}{*}{\begin{tabular}{|c|} 
Private School \\
$\%$ of children (age \\
$6-14$ ) enrolled in \\
private school \\
\end{tabular}} & \multicolumn{2}{|c|}{ Learning Levels: All Schools } \\
\hline & & & Std III-IV & Std VI-VIIII \\
\hline & & & $\%$ of children who & \% of children who \\
\hline & & & can read std II text & can read std II text \\
\hline Central & 0.4 & 14.0 & 60.3 & 78.1 \\
\hline North & 0.8 & 9.6 & 46.2 & 68.3 \\
\hline South & 3.5 & 6.9 & 38.1 & 56.4 \\
\hline Malkangiri & 7.1 & 2.6 & 14.0 & 53.2 \\
\hline Odisha & 1.5 & 10.5 & 49.0 & 68.9 \\
\hline
\end{tabular}

Source: Pratham's Annual State of Education Report (Rural) 2018.

Malkangiri is lagging behind in all the aspects taken into consideration. Around $7 \%$ of the total no. of children aged 6-14 are not enrolled in school. Shockingly around $86 \%$ of Std. III-IV students cannot read a Std. II textbook and around $47 \%$ of Std. VI-VII students cannot read a simple Std. II textbook. This also indicates a very important aspect of education in the rural regions of the State that is student's learning capacity. Given the total amount of schools being built or the rigorous teachers' training programme it is also essential to know whether the child is being provided all the necessary basic amenities required for a healthy mind. If the child is mentally and physically unfit, all the efforts in training them becomes futile.

Table 5.

\begin{tabular}{|c|c|}
\hline Household Data & $\%$ \\
\hline \% of households who do not own have own dwelling & 5.52 \\
\hline \% of households who depend on kerosene/ bio fuel for & 80.54 \\
\hline illumination & 90.66 \\
\hline \% of households who do not have no latrine facilities & 90.36 \\
\hline \% of households who depend on biofuel for cooking & 95.77 \\
\hline \% of households who have availed banking facilities & 29.64 \\
\hline
\end{tabular}

Source: District Census Handbook 2011

The housing or permanent settlement data state that around $5.5 \%$ of the district's population live in rented settlement. This proves that State has taken adequate measures to provide housing to the maximum residents in the district. While this have added feathers in the state's cap there are certain other parameters which have downgraded the region's progress. With more than $80 \%$ of the residents depending on the biofuel such as kerosene, firewood, coal and cow-dung for cooking and lighting purpose the region needs to focus on provision of electricity and LPG/PNG. Dependence on biofuel can affect the health of females who inhale the carcinogenic dust from the smoke. Around 91\% of the residents have no toilet facility. They depend on public toilets or other alternatives which can definitely adversely affect their health especially female hygiene during menstruation. 
With no proper drainage system to dispose the waste material, it is all dumped in the water bodies. As a result the groundwater gets polluted, and in times of heavy rain, roads and canals gets flooded with the unwanted material. For this reason the health, education and income indices bare the lowest scores $0.122,0.491$ and 0.497 respectively. This lowers the entire Human Development Index of the district as a whole. One of major reasons behind dropping out of school is also the physical and mental illness due to poor nutrition and living in unhygienic condition.

Table 6.

\begin{tabular}{|c|c|}
\hline Health in Malkangiri & \\
\hline primary health care centres & 24 \\
\hline community health care centres & 8 \\
\hline area hospital & 4 \\
\hline nutritional rehabilitation centres & 2 \\
\hline no. of doctors & 56 \\
\hline
\end{tabular}

Source: Malkangiri.nic.in

The above table illustrates the Government's efforts to provide healthcare facilities in the region. Though there have been improvements the district still lags behind in providing required number of health-care centres and doctors with a huge amount of vacancies yet to be filled.

\section{RESULT}

When we compare the data of districts with high literacy rates (such as Khordha, Cuttack and Angul) with that of Malkangiri we find that the no. of schools, teachers, hospitals, healthcare centres as well the no. of doctors are more in number in the former districts. Even the per capita income is high in those districts as compared to Malkangiri.

The state government has announced a budget of Rs. 22,631 Crore for the development of education and an additional Rs. 29,000 Crore for nutrition sensitive schemes in the budget [12]. This makes one very important revelation that instead of outlays, schemes should be outcome driven. Every penny counts in calculating the Fiscal deficit. So it must be ensured that the schemes do not prove to be extravagant and end up benefiting nobody.

\section{CONCLUSION}

India has, time and again, charmed the world with its knowledge and brilliance. The country has astounded the world with scholars like Aryabhata, Chanakya, Sushruta, Raja Ram Mohan Roy, Dr. C.V. Raman and Dr. A.P.J. Abdul Kalam. Undoubtedly our nation has always been an epitome of talent and wisdom around the Globe. But as they say heavy lies the head that wears the crown. With such proficiency comes the responsibility of tackling the worries of growing population, quality education and job creation.

Union Government has pledged to allocate around Rs. 99,300 Crore for budgetary expenditure on education sector this year [13]. A 5\% rise in the allocation since 2019-2020 Budget can add up to the exchequer if not improve the situation. According to literacy rate India's rank is 164 among 234 countries. According to the education index formulated by the United Nations our country ranks 145 out of 191 countries. As per the Programme for International students Assessment formulated by Organisation of Economic Co-operation and Development India ranks $72^{\text {nd }}$ among 74 countries. If we evaluate all the rankings we are mostly placed among the bottom $25 \%$ of the data. Even after 70 years of implementation of the Five year plans the human capital resource of India is not competent enough. Let's take a closer look at the state of Education in China [14] for instance, it has achieved the goals of Universal education with the highest amount of graduates and international students all over the world. The country generates around 80 lakh High school graduates annually and has increased net enrolment ratio for tertiary education to about $50 \%$ within the last decade. Given the economic growth of the country it is evident that education system is one of the major reasons behind making China an industrial conglomerate. With Institutes like Peking University, Tsinghua University and Zhejiang University China produces top notch engineers, doctors, technocrats, lawyers and researchers who support the economic framework of the country. But this couldn't have been possible without the strong backing of the primary and senior level education which is compulsory for children in rural and urban areas irrespective of their class or gender.

As far as strengthening education in Malkangiri is concerned, education should be made mandatory until high school and drop-out before that punishable. Skill development should be encouraged on terms of completion of high school. Even skill development should be more like a degree course but quick and focusing more on practical scenario. A committee should be set up for each block to review the progress of every alternative class from Std. II onwards. The committee should comprise of teachers and professors who do not belong to that particular district. Parents should be allowed to be there in the evaluation of their kid. This will encourage the student to improve. With scholarship programmes and Mid-day meals schools should also be more vigilant about each child's development holistically and mention that in the report card. Studies have shown that most of the dropouts have been because of poor hygiene in the school itself. For this reason toilets should be mandatorily built and properly maintained in every school in the district. Low cost biodegradable sanitary napkins should be made available in each toilet. The schools which showcase a poor record of students, teachers, staff, or the infrastructure an Ad Hoc committee should be set up to regularize the subject matter and implement rules and regulations for quick action. If the issues in the grass-root level are sorted out immediately, it won't bubble up to become a monstrous budgetary matter later on.

\section{REFERENCES}

1. Jay Newman (1977). Education as Civilization. The Journal of Educational Thought. Volume 11, No.3, pp 203-212.

2. Human Development Index 2017. United Nation Development Programme. Retrieved From https://www.in.undp.org/content/india/en/home/sustainable- and $\mathrm{Hum}$

(C) Copvriaht: All riahts reserved. 
development/successstories/india-ranks-130-on-2018-humandevelopment-index.html.

3. Millenium Development Goals. Retrieved From- in.UNDP.org.

4. Sustainable Development Goals. UNDP. Retrieved From https://www.in.undp.org/content/india/en/home/sustainabledevelopment-goals.html.

5. Pratham's Annual Status of education Report 2018-19. Retrieved From

http://img.asercentre.org/docs/ASER\%202018/Release\%20Material/a serreport2018.pdf.

6. Amartya Sen and Jean Dreze (2003). Basic education as a political issue. Education, society and social development.

7. Sujatha, K. (2002) Education among Scheduled Tribes. In Govinda, R. (ed.), India Education Report: A Profile of Basic Education. New Delhi: Oxford University Press.

8. Kumar Rana, Samantak Das, Amrita Sengupta, Abdur Rafique (2003). State of Primary Education in West Bengal. Economic and Political Weekly.

9. Nirupam Bajpai, Ravindra H. Dholakia and Jeffrey D. Sachs (2005) Scaling Up Primary Education Services in Rural India. The Earth Institute at Columbia University (www.earth.columbia.edu)

10. Sylvie Kobzev Kotásková, Petr Procházka, Luboš Smutka, Mansoor Maitah, Elena Kuzmenko, Markéta Kopecká, Vladimír Hönig (2018). The impact of education on economic growth: the case of India. Acta Universitatis Agriculturae et Silviculturae Mendelianae Brunensis. Volume 66.

11. District Census Handbook 2011. Retrieved From https://censusindia.gov.in/2011census/dchb/2130_PART_B_DCHB_ MALKANGIRI.pdf.

12. Odisha Budget 2020-21. Retrieved From https://budget.odisha.gov.in/.

13. Union Budget 2020-21. Retrieved From https://www.indiabudget.gov.in/.

14. Education in China Retrieved From https://www.oecd.org/china/Education-in-China-a-snapshot.pdf.

\section{AUTHOR'S PROFILE}

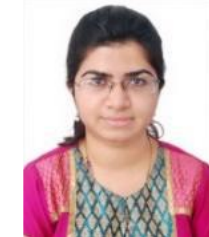

Ms. Subhra Parida, has completed her postgraduation in Science from Gokhale Institute of Politics and Economics, specializing in the field of agribusiness economics. She is currently pursuing Ph.D. at KIIT School of Humanities. Her current area of research is 'Indian Agriculture'. She has qualified UGC NET and has also published 2 research papers in Scopus-indexed Journals. 